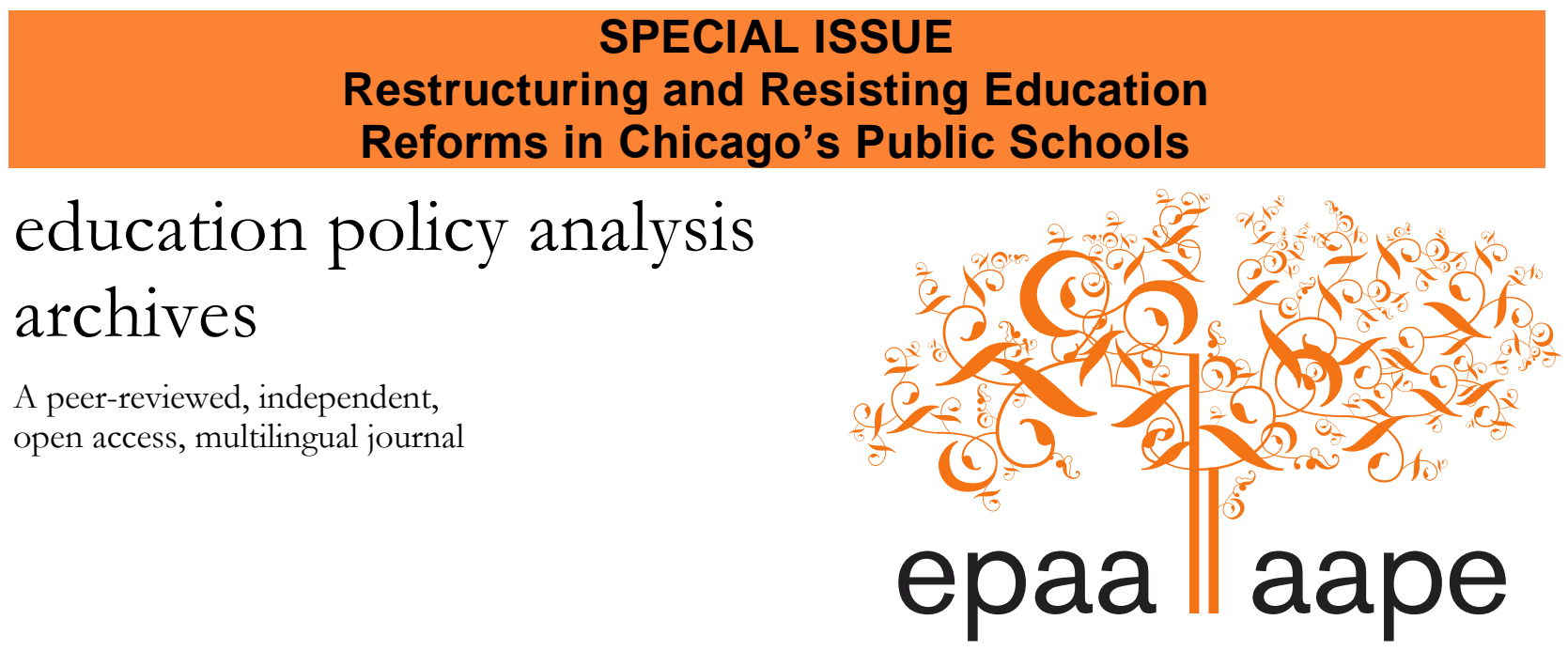

Arizona State University

June 5, 2017

ISSN 1068-2341

\title{
Neoliberalism, Resistance, and Self-Limiting Language
}

\author{
Christopher Lubienski \\ Indiana University \\ United States
}

Citation: Lubienski, C. (2017). Neoliberalism, resistance, and self-limiting language. Education Policy Analysis Archives, 25(60). http://dx.doi.org/10.14507/epaa.25.2991 This article is part of EPAA/AAPE's Special Issue on Restructuring and Resisting Education Reforms in Chicago's Public Schools, Guest Edited by Federico Waitoller and Rhoda R. Gutierrez.

Abstract: This discussion offers an overview of the articles and themes developed by the papers in this special issue on Chicago school reform, and also some critical comments on such scholarship. It highlights how these reforms are not organic, as they are often portrayed, but are instead a result of strategic efforts by policymakers and special interests. As the authors of these articles show, these reforms essentially experiment with education "innovations" on poor and minority children in a context where segregation appears to be increasingly accepted. But while the efforts of equity-minded researchers in addressing these issues should be lauded, this discussion goes further and offers some critical commentary on researchers' use of language, arguing that we too often alienate ourselves from both the policymakers we seek to influence and from the people we seek to help. By adopting exclusive language common in critical theory's attack on "neoliberalism," scholars may try to enhance their own credibility by demonstrating familiarity with obscure terminology, but in doing so, may be creating another echo-chamber which excludes them from policy discussions that can effect substantive change.

Keywords: education policy, education reform, equity, critical theory 


\section{Neoliberalismo, resistencia y lenguaje autolimitado}

Resumen: Esta discusión ofrece una visión general de los artículos y temas desarrollados por los artículos en esta edición especial sobre la reforma de la escuela de Chicago y también algunos comentarios críticos sobre esta beca. Destaca cómo estas reformas no son orgánicas, como a menudo se retratan, pero son, en cambio, resultado de esfuerzos estratégicos de responsables políticos e intereses especiales. Como muestran los autores de estos artículos, estas reformas experimentan esencialmente las "innovaciones" de educación sobre niños pobres y minoritarios en un contexto en el que la segregación parece ser cada vez más aceptada. Pero, aunque los esfuerzos de los investigadores de mentalidad equitativa para abordar estas cuestiones deben ser alabados, esta discusión va más allá y ofrece algunos comentarios críticos sobre el uso del lenguaje por parte de los investigadores, argumentando que con demasiada frecuencia nos alejamos de los diseñadores de políticas que buscamos influir y de las personas que queremos ayudar. Al adoptar un lenguaje común común en el ataque de la teoría crítica al neoliberalismo, los estudiosos pueden intentar aumentar su propia credibilidad demostrando familiaridad con la terminología oscura, pero, al hacerlo, puede estar creando otra cámara de eco que excluye las discusiones políticas que pueden afectar el cambio sustantivo.

Palabras-clave: política educativa; reforma de la educación; equidad; teoría crítica

\section{Neoliberalismo, resistência, e linguagem auto-limitante}

Resumo: Esta discussão oferece uma visão geral dos artigos e temas desenvolvidos pelos artigos nesta edição especial sobre a reforma da escola de Chicago e também alguns comentários críticos sobre essa bolsa de estudos. Ele destaca como essas reformas não são orgânicas, como muitas vezes são retratadas, mas são, em vez disso, resultado de esforços estratégicos de decisores políticos e interesses especiais. Como mostram os autores desses artigos, essas reformas experimentam essencialmente as "inovações" de educação sobre crianças pobres e minoritárias em um contexto em que a segregação parece ser cada vez mais aceita. Mas, embora os esforços dos pesquisadores de mentalidade equitativa para abordar essas questões devem ser louvados, essa discussão vai além e oferece alguns comentários críticos sobre o uso dos idiomas pelos pesquisadores, argumentando que também nos alienamos dos formuladores de políticas que procuramos influenciar e de as pessoas que procuramos ajudar. Ao adotar linguagem exclusiva comum no ataque da teoria crítica ao "neoliberalismo", os estudiosos podem tentar aumentar sua própria credibilidade demonstrando familiaridade com a terminologia obscura, mas, ao fazê-lo, pode estar criando outra câmara de eco que exclui as discussões políticas que podem afetar mudança substantiva.

Palavras-chave: política educação; reforma educação; eqüidade; teoria crítica

\section{Neoliberalism, Resistance, and Self-Limiting Language}

The global trend toward market models for public policy is in many places met with increasingly organized resistance (Klein, 2007). These "neoliberal" policy models are often framed as the natural emergence of individual liberty, economic-style consumer choice, deregulation and a general roll-back of state administration and oversight of public goods and services, particularly since the fall of state command economies in the 1980s and 1990s (Yergin \& Stanislaw, 1998). But these policies are not simply an organic unfolding of a new order based in classic liberal economic assumptions of individual freedom articulated in social spaces freed from state interference. In fact, they are the result of concerted efforts by an array of think tanks, policy entrepreneurs, public 
officials and private interests who have orchestrated policy change in ways aligned with their proprivatization agenda, and often their self-interest (Lubienski, Brewer, \& Goel La Londe, 2016).

But at the same time, an array of "stakeholders" (to borrow a term from neoliberal policy rhetoric) have pushed back against these trends, and are becoming more strategic and effective in resisting these reforms. From Chilean students demonstrating against education policies, to indigenous communities taking control of their own resources, to new media activists exposing abuses by policy elites, new opposition networks are forming. These networks sometimes represent a considerable challenge to the seemingly inexorable encroachment of market models onto areas of life that have traditionally been seen as being beyond the purview of market-style arrangements (Kuttner, 1999; Sandel, 2012).

One key element of these new strategic networks is the role of researchers and activists who document the impacts of these policies, often examining the disjuncture between the assumptions, rhetoric, and results of such reforms. By leveraging analytical skills, access to data, and some credibility in policy discussions, these people are positioned to contribute important insights on how these policies impact communities in the crosshairs: children in areas of concentrated poverty, children with special needs, families who lack stable housing, public employee and teacher unions, and so forth. The papers in this special issue highlight such work by an array of scholars focused in different ways on education inequities in Chicago. The work they present here spans methodological approaches, from qualitative inquiry to descriptive statistics. But they share a common and pronounced concern with the equity impacts of the education reform policies that have been imposed on the citizens of Chicago in recent years. In the following, I highlight some of the findings of their research, and draw out particular themes that may be useful for making sense of the special issue as a whole. Then, in the remainder of this brief, introductory commentary, I outline some of the challenges facing researchers pursuing this line of inquiry, and discuss some potential ways that we can advance the findings of such significant work more squarely into influencing the policymaking arena.

\section{School Reform, Chicago-Style}

Although the trend toward using market models is indeed a global phenomenon, it appears in different manifestations in different contexts, of course, reflecting the influence of historical, institutional, demographic, policy, and other factors. The focus of the papers in this special issue is on Chicago, which, in some ways, represent the epitome of neoliberal education reforms, according to these analysts. While post-Katrina New Orleans is often (and rightly) seen as the epicenter for market-style reforms in education, it should be noted that this is partly due to the fact that reform advocates who cut their teeth in Chicago education policy hurried down to Louisiana after the hurricane to advance a market-based alternative to displace — or "disrupt" in neoliberal parlance (Christensen, Horn, \& Johnson, 2008) - the traditional public system of education (Klein, 2007; Richmond, 2007). Interestingly enough, another global hot-spot for these types of reforms has been Chile since the Pinochet Coup overthrowing President Allende. There, the influence of the "Chicago Boys" - students trained in neoliberal economics at the University of Chicago — has been well documented in their creation of a comprehensive national voucher program that saw the growth of the private, proprietary sector in education (Espínola, 1993; Gauri, 1998; Klein, 2007).

But even while its areas of influence might be more dramatic than the reforms in Chicago itself, the policies that have been put into place over the last few mayoral administrations in Chicago are very much worthy of attention. Indeed, after having attempted significant education reforms before, but still facing massive segregation, inequality, and failure, Chicago's elites, led by the city's 
Commercial Club, embraced a set of structural reforms that focused less on curriculum and instruction, and more on school governance and accountability.

While the authors in this special issue do a wonderful job of describing the evolution and implementation of these policies, the question still emerges as to why we should pay attention to the reforms in Chicago. Even though it is the third largest school districts in the nation, it also shares characteristics and experiences with other large American cities, especially in the Rust Belt, in terms of entrenched segregation, large areas of concentrated poverty, generations of inequitable outcomes, stories of inefficiencies and corruption, as well as the move toward mayoral control, the growth of charter schools and other options, the influence of economic elites in shaping education policy, and so forth. Detroit has seen similar patterns, as has Philadelphia, Kansas City, Cleveland, and St. Louis. But Chicago also presents a very instructive case.

Unlike other Rust Belt cities, like Detroit, for instance, Chicago has maintained a much more diversified and dynamic economic base, and has not seen "white flight" on the same scale as some other cities that have populations that are now overwhelmingly minority. The city has large communities of young, professional, and wealthy residents associated with its world-class universities, businesses, and service industries, as well as established working class communities. But economics and demographics aside, the policy climate in Chicago - as a "laboratory," to use Pauline Lipman's term (in this issue) — is what recommends it for study. As the authors of these articles describe so adeptly, Chicago (and Illinois) policymakers pushed a coherent set of policies that reconfigured not only the school system as well as other public services, but the relationship between those governed and their government, the spatial politics of the city, and the models for education, policy influence, and political engagement subsequently available across the US and beyond. Most importantly, while Chicago is rather distinct from many other cities in the pace and scale of its education reforms, it not unlike many other places, or times, in how it represents a concerted effort by elites to impose an education policy on the more disadvantaged in the community. Indeed, it serves as an example of social experimentation on other people's children.

The papers in this collection critically examine this policy implementation and social experimentation in the Chicago context from several different angles, usually centering on the momentous decision to close dozens of Chicago Public Schools that were overwhelmingly located in, and serving, African American communities. In "Desire for Democracy," Kelly Vaughan and Rhoda Rae Gutierrez look at the imposition of these policies in terms of the changing historic purposes of public education. Even though public education has never lived up to the great "balance-wheel of the social machinery" - in Horace Mann's imagery — because of its chronic and substantial shortcomings in offering equitable opportunities (much less outcomes) for all, the authors note how public education has represented an ideal that is now very much under attack, if not forgotten in most official policy circles. It is interesting to remember the degree to which liberal and leftist critiques of public education have been coopted by the market fundamentalists, or "marketists," now attacking state involvement in public education (Lubienski \& Lubienski, 2014). For example, in the 1970s and 1980s, radical critiques of the failures of public education, coming from the left, focused on the failure of public schools to meet the needs of marginalized students, and were then used by the Treasury in New Zealand to argue for the need to provide more choice and autonomy by moving toward more market-style arrangements (Treasury, 1987). Vaughn and Gutierrez illuminate similar dynamics, where the language of the American movement for civil rights has been appropriated by neoliberal reformers to justify moves toward market models in education (see also Jankov and Caref, in this issue). They show that families who are subjected to these new reforms do not trust the supposedly transparent and democratic (including large D Democratic) policy processes and elites to do what is in the best interests of their communities' children. 
The article, "Seeking Stability in Chicago," from Ann M. Aviles and Jessica Heybach, focuses on the impact of these policies, particularly on homeless students. Drawing on Critical Race Theory, they provide both theoretical and legal analyses, alleging that the policies actually violate the law. In this collection of papers, "Seeking Stability in Chicago" stands out for the authors' consideration of housing policy in Chicago, which has, of course, contributed to the segregative patterns in schools as well. But race plays a primary role in their analysis, where they reveal, for instance, the concerning and telling fact that " $73 \%$ of all money went to schools where white students make up more than a quarter of the student body (only $12 \%$ of Chicago's schools have more than $25 \%$ white students)."

Looking at another vulnerable population while using a critical theoretical lens, Federico Waitoller and Gia Super consider the ways in which African American and Latino/a families with special needs children negotiate the new landscape of school choice in Chicago. Using an innovative critical geographic approach, they carefully document the disappearance-by-design of children with special needs from Chicago's educational landscape, smartly situating the voices of those parents within specific localities. In this landscape, charter schools serve dual roles: as filtering devices in gentrification processes, and as spaces for those pushed out of local housing or shuttered schools. By problematizing conceptions of space, they also question the idea that "choice" is more widely available, showing that some choices are sought, while others are essentially imposed. Their conclusions comport with the excellent work done by Julia Burdick-Will (2015) showing that Chicago's wealthier families indeed have choice (as choice advocates never tire of reminding us), but are better positioned to choose to go to a local school, while more disadvantaged families now have a choice, but that often means traveling much further, and for schools that are not necessarily better (see also Burdick-Will, Keels, \& Schuble, 2013; Lee \& Lubienski, 2017).

The powerful piece from Pavlyn Jankov and Carol Caref focuses on segregation of AfricanAmerican students - and particularly on those that are economically disadvantaged — as well as teachers, most harmed by school closure policies. Their article attends to the rhetoric versus reality of neoliberalism, and brings some empirical evidence to bear on neoliberal use of civil rights rhetoric. For instance, according to the authors, as of 2012, 60\% of African American elementary students in Chicago Public Schools were in schools that were serving a student population that was both at least 90\% African American and 90\% eligible for Free/Reduced Lunch, up from 38\% in 1981. But they also bring teachers into the equation, which is an important consideration, since public school teaching has often been a pillar of the African American middle class in the US. They note that by 2012, "the number of schools where there are no Black teachers on staff has more than tripled from 10 to 37." Of course, some might argue that the Chicago reforms may help, by freeing up families to choose their children's schools, and deregulating entry into the teaching force. But the authors find that is not necessarily the case. In charter schools, which have become the go-to model for Chicago policymakers, Jankov and Caref report that $60 \%$ of the students are African American, but only $18 \%$ of the certified teachers are. And African American students are increasingly likely, compared to all students, to have beginning teachers ( $8.9 \%$ v 5.3\%); although African American students in charter schools have a $25 \%$ chance of getting an inexperienced teacher.

Finally, two eminent scholars provide overviews not only of Chicago, but of the implications of Chicago's reforms for education policy across the US, and across the globe. While other scholars are arguing about test scores and other minutiae, Kenneth Saltman has demonstrated an amazing and enviable ability to see and analyze significant trends, such as militarization, corporatization, and the rising power of philanthropies, that may not be as apparent to most scholars. In the fascinating "Promise and Realities of Pay for Success Social Impact Bonds," Saltman examines an "innovative" approach popular with policymakers of encouraging private capital to fund public services on a forprofit basis, purportedly with the idea that they are incentivized to be more innovative, effective and 
efficient at this than is the public sector. Once again, Chicago has served as a laboratory for this social experiment on poor people. But Saltman shows that this approach not only enriches private actors, it is squeezing the supposed beneficiaries. Moreover, while it is advanced as an innovative policy approach, in fact it disincentivizes innovation, encouraging these organizations to shirk any financial risk.

Perhaps the "dean" of education policy studies of Chicago, Pauline Lipman offers an excellent overview of the "racialized" aspects of Chicago's reforms, showing how Chicago has served (for better or for worse, but mostly for worse) as a model of education reform. In this critical examination of the landscape of Chicago's policies, Lipman draws on her own considerable experiences as a scholar-activist to understand not just the creation and implementation of these policies, but the community- and labor-based resistance they have provoked. Looking at the political economy of Chicago's reforms, Lipman observes both the global logic of neoliberalism, and the context-dependent aspects reflected in neoliberalism's fluidity. She notes that there is a mixed record of triumphs and defeats in opposing these policies, but that the most successful resistance is in the collation of labor and community activism.

\section{Common Themes}

Together, these papers present a very coherent portrait of what is happening in Chicago, and the implications for public education in general - and that's a problem (as I note below). But before I discuss the problematic aspects of this, it is useful to highlight some of the common themes from this case:

- These reforms are not simply an organic emergence of an appreciation for individual liberty (manifested in school "choice") and rolling back state interference (as seen in deregulation and increasing organizational autonomy). Instead, the authors show how the reforms are the result of a strategic effort by elites to advance a particular set of policies, and there are winners and losers from these efforts. The papers demonstrate the teachers unions and many disadvantaged and marginalized families have been on the short end of the stick, while school management chains and private funders have seen gains in their power and influence. But these patterns beg the question: Why does these groups get to call the shots? Just as no one ever cast a vote for Bill Gates to experiment on our children first with small schools, and then with charters and the Common Core (Layton, 2014), the Civic Committee of the Commercial Club of Chicago is an unelected and unaccountable body that laid out a blue print for these reforms. While that effort may have been well-intentioned, in was also created by a body that is not representative of the communities on which these reforms are imposed.

- These reforms are an example of experimentation on working-class and minority children and communities. This, of course, is an old story, where middle-class reformers intervene to do what they think is best for poor children. But such interventions also involve the imposition of almost exclusively middle-class and affluent perspectives on diverse communities. In this case, the fact that many of the reforms, such as charter schools and Pay for Success, have mixed or unproven records highlights the role that these communities play as guinea pigs for this experimentation, while wealthier Chicago suburbs seem to be happy to embrace tried 
and true approaches, being largely shielded from the imposition of such experimentation.

- The fact that these papers consistently highlight the pervasive and detrimental effects of segregation in Chicago, while policymakers do little if anything to directly address those problems, raises the concern that segregation is simply no longer an issue on the policy agenda. The old idea of common schooling, and the notion of equitable distribution of educational resources, do not appear to be guiding policy discussions to any significant degree, despite the concerns raised by these papers.

- The papers here document a struggle for influence between policy elites and experts. The education policy measures in Chicago came largely from business-oriented reformers who drew on the logic of the business world in re-imagining an education system that better reflected that logic. At the same time, researchers were highlighting significant concerns about the efficacy of those approaches, as well as their detrimental impacts. Yet those concerns did not appear to carry the day.

- All of these papers dwell, more or less explicitly, on "neoliberal" policies, their logic, implementation, and impact. But as these are generally critical analyses, what we see less of is the allure of neoliberal approaches for policymakers and for various constituencies. It is important to note that, faced with the hard and expensive tasks of truly addressing the entrenched problems facing educators (Rothstein, 2004), policymakers often prefer instead to simply offer "choice" or "deregulation." Of course, in doing so, they shift the burden for failure from the government to individuals who may make "bad choices," but "the lure of the structural panacea," to use David Tyack's (1974, p. 169) term, is hard to resist, especially in an age of selfimposed austerity due to tax cuts and self-inflicted budget crises, as Illinois is facing.

- The focus on race permeates these papers, as it should, especially considering the Chicago context. However, a less prominent (although by no means absent) consideration is the question of class. It will be interesting to see how future research takes into account recent findings that highlight the role that socioeconomic status plays as a relatively better predictor of school opportunities and outcomes (Reardon, Robinson-Cimpian, \& Weathers, forthcoming).

- Finally, these papers as a whole highlight the usefulness for taking a critical approach that is based in contextual considerations, such as local policies, historical patterns, demographic arrangements, and so forth. In particular, the Waitoller and Super article demonstrates the advantages of taking a critical-geographic perspective that takes into account both measurable elements of space (such as proximity and routes), as well as qualitative conceptions of space, which reflect perceptions of proximity, power differences, access and exclusion (Lubienski \& Lee, 2017).

Thus, the papers collectively advance many important themes. But, as I argue in the concluding discussion, they also point to the need to consider next steps. In particular, they suggest the need to develop a language that more effectively influences policy discussions. Simply using terms that a relatively small group of researchers understand prevents research from penetrating policy 
discussions. And it too often prevents us from digging in more deeply to concepts that deserve greater understanding and analysis. For instance, these papers collectively attack "neoliberalism," and some do a wonderful job of defining the term. However, there is little exploration of the (false) appeal of neoliberal solutions, not its internal contradictions. For instance, is neoliberalism really a top-down form of policy imposition or accountability framework, as some of these suggest? Neoliberals would argue — incorrectly, in my view — that they are doing the opposite, by creating structures that allow for the localized articulation of preferences, thereby nurturing the grassroots of communities. Such contradictions deserve further investigation.

\section{Language and Self-Imposed Limitations}

When we have such a set of coherent and compelling analyses, we might ask: So now what? Now that researchers have brought evidence to bear in making a case about the problems with popular policies, what can they — or we, as a scholarly community — do to ensure that such findings are heard and have an impact? Certainly, publishing in an open-access journal such as this is an important first step, since it removes barriers to accessing the research. But it is not sufficient.

As I noted above, there is an underlying problem here, and that is that we are too often preaching to the choir - and that choir may be getting more and more exclusive and introspective. A simple bibliometric analysis here makes the point (and my apologies in advance to the authors). These papers deal with neoliberal reforms in education. Thus, there are numerous references to the critical work of Stephen Ball, Gloria Ladson-Billings, Tom Pedroni, Michael Apple, David Gillborn and others - as there should be because these eminent scholars shine a critical light on such reforms. But consider what is missing. There is no reference to Milton Friedman, the Nobel Laureate who, while at the University of Chicago, became one of the primary intellectual authors for such policies (Friedman, 1962). The work by Osborne and Gaebler (1992), who helped pioneer the ideas that would then take root in Chicago, is not considered. Likewise, John Chubb and Terry Moe's (1990) influential analysis on choice and autonomy — which would be relevant here - is mentioned in only one paper. Rigorous work by David Figlio (at Northwestern University just north of Chicago) and others of the apparent benefits of competition for public schools is not touched (Figlio \& Karbownik, 2016).

Of course, I am not saying that authors need to have a checklist of citations to knock down. What I am pointing out is that we are creating our own echo chambers in our research: citing likeminded scholars, publishing for what are likely sympathetic audiences, and failing to engage a diversity of perspective, or other forms of evidence.

A primary way researchers do this is through our language (something that I myself also struggle with). Of course, specialized research sometimes requires arcane technical terminology. But such language is too often also used to simply enhance a researcher's credibility by showing familiarity with state-of-the-art jargon. It can also undercut efforts to aid the very people we seek to assist with our findings by making research less accessible, and more exclusive. This is particularly concerning in an era when concern about the proper terminology for different groups has been swept aside by political forces that seek to do substantive harm to education, healthcare, and other social services while researchers anguish over symbolism. Researchers marginalize themselves when we debate whether it should be "Latino/a," "Latinx," or "Latin@," at the same time that the US President (who consistently and unapologetically refers to a political opponent as "Pocahontas") is dismantling the social safety net while enjoying much support from working-class voters who are liable to lose both their health care and their access to quality public schools.

So, with respect to language, terms like "neoliberalism" come up quite frequently in critical analyses of education policy (and this tendency is not exclusive to these papers, but is pervasive 
across critical theory). But, although I do much work in this area, I've never met anyone who describes themselves as a "neoliberal" (although I did have one person — knowing I am an academic — half-jokingly threaten to throw me out of her office if I used that term). Nonetheless, researchers' insistence on using such terminology, although it certainly serves a descriptive purpose, comes at the risk of alienating people who could benefit from critical analyses, as well as policymakers who need to be convinced about the concerns critical theorists are raising. Social science and public policy move forward through disagreement and discussion. But when we build linguistic echo-chambers for ourselves, we pre-empt this possibility. Scholarly activism has its place, but would be much strengthened by engaging rather than precluding these discussions, drawing on the terminology used by policymakers and regular people.

When I observe or am involved in policy discussions where actual decisions get made, both the vocabulary and evidence researchers and policymakers use is far removed from what is common in critical theory. As we know, education research, and especially qualitative methods, are often sidelined in favor of econometric analyses and assumptions in education policymaking. And this lesson has been learned by organizations promoting market models for education, who arm themselves both with seemingly uncontestable quantitative data, and with vocabularies that allow for access to broader audiences, including policymakers.

Thus, in conclusion, it is useful to ask ourselves about the purpose of the research that we do. An important function, often reflected in this special issue, is to document the impact of polices, and in particular the distance between the rhetoric that was used to promote such policies, and their actual results. Another, also reflected here, is to offer an alternative analytical lens from which to consider and conceptualize policy problems. But still another use for research findings is to persuade, to encourage the adoption of alternative policies and goals. Here, those of us interested in critical analyses would do well to consider how we can engage more effectively in popular and policy discussions, and perhaps pay some attention to how market advocates and neoliberals have been so successful in that regard.

\section{References}

Burdick-Will, J. (2015). School Choice, Neighborbood Income, and Educational Heterogeneity. Paper presented at the American Sociological Association, Chicago.

Burdick-Will, J., Keels, M., \& Schuble, T. (2013). Closing and Opening Schools: The Association between Neighborhood Characteristics and the Location of New Educational Opportunities in a Large Urban District. Journal of Urban Affairs, 35(1), 59-80. https://doi.org/10.1111/juaf.12004

Christensen, C. M., Horn, M. B., \& Johnson, C. W. (2008). Disrupting Class: How Disruptive Innovation Will Change the Way the World Learns. New York: McGraw-Hill.

Chubb, J. E., \& Moe, T. M. (1990). Politics, Markets, and America's Schools. Washington, DC: Brookings Institution.

Espínola, V. (1993). The Educational Reform of the Military Regime in Chile: The School System's Response to Competition, Choice, and Market Relations. (Ph.D. diss.), University of Wales, Cardiff. Retrieved from http://www.theses.com/idx/043/it043008374.htm

Figlio, D. N., \& Karbownik, K. (2016). Evaluation of Ohio's Edchoice Scholarship Program: Selection, Competition, and Performance Effects: Thomas B. Fordham Institute.

Friedman, M. (1962). Capitalism and Freedom. Chicago: University of Chicago Press.

Gauri, V. (1998). School Choice in Chile: Two Decades of Educational Reform. Pittsburgh: University of Pittsburgh Press. 
Klein, N. (2007). The Shock Doctrine: The Rise of Disaster Capitalism (1st ed.). New York: Metropolitan Books/Henry Holt.

Kuttner, R. (1999). Everything for Sale: The Virtues and Limits of Markets. New York: University of Chicago Press.

Layton, L. (2014, June 7). How Bill Gates Pulled Off the Swift Common Core Revolution. Washington Post. Retrieved from http://www.washingtonpost.com/politics/how-bill-gatespulled-off-the-swift-common-core-revolution/2014/06/07/a830e32e-ec34-11e3-9f5c9075d5508f0a_story.html

Lee, J., \& Lubienski, C. (2017). The Impact of School Closures on Equity of Access in Chicago. Education and Urban Society, 49(1), 53-80. https://doi.org/10.1177/0013124516630601

Lubienski, C., Brewer, T. J., \& Goel La Londe, P. (2016). Orchestrating Policy Ideas: Philanthropies and Think Tanks in Us Education Policy Advocacy Networks. Australian Education Researcher, 43(1), 55-73. https://doi.org/10.1007/s13384-015-0187-y

Lubienski, C., \& Lee, J. (2017). Geo-Spatial Analyses in Education Research: The Critical Challenge and Methodological Possibilities. Geographical Research, 55(1), 89-99. https://doi.org/10.1111/1745-5871.12188

Lubienski, C., \& Lubienski, S. T. (2014). The Public School Advantage: Why Public Schools Outperform Private Schools. Chicago: The University of Chicago Press.

Osborne, D., \& Gaebler, T. (1992). Reinventing Government: How the Entrepreneurial Spirit Is Transforming the Public Sector. New York: Plume.

Reardon, S. F., Robinson-Cimpian, J. P., \& Weathers, E. S. (forthcoming). Patterns and Trends in Racial/Ethnic and Socioeconomic Academic Achievement Gaps. In H. A. Ladd \& E. B. Fiske (Eds.), Handbook of Research in Education Finance and Policy (2nd ed.). Mahwah, NJ: Lawrence Erlbaum. https://doi.org/10.4324/9780203961063.ch28

Richmond, G. (2007, April 18). Piecing Together the Charter Puzzle. Education Week, 26, 28-29. Rothstein, R. (2004). Class and Schools: Using Social, Economic, and Educational Reform to Close the BlackWhite Achievement Gap. Washington, DC: Economic Policy Institute.

Sandel, M. J. (2012). What Money Can't Buy: The Moral Limits of Markets. New York: Farrar, Straus and Giroux.

Treasury. (1987). Government Management: Volume Ii - Education Issues. Wellington, NZ: Government Printer.

Tyack, D. B. (1974). The One Best System: A History of American Urban Education. Cambridge, MA: Harvard University Press.

Yergin, D., \& Stanislaw, J. (1998). The Commanding Heights: The Battle between Government and the Marketplace That Is Remaking the Modern World. New York: Simon \& Schuster. 


\title{
About the Author
}

\begin{abstract}
Christopher Lubienski
Indiana University and East China Normal University

clubiens@iu.edu

Christopher Lubienski is a Professor of education policy at Indiana University, and also a fellow with the National Education Policy Center at the University of Colorado and Visiting Professor at East China Normal University in Shanghai. His research focuses on education policy, reform, and the political economy of education, with a particular concern for issues of equity and access. His recent book, The Public School Advantage: Why Public Schools Outperform Private Schools (with co-author Sarah Theule Lubienski, University of Chicago Press), won the 2015 PROSE Award for Education Theory from the American Publishers Awards for Professional and Scholarly Excellence, and his next book, The Impact of Market Mechanisms on Educational Opportunity around the Globe (co-edited with Bekisizwe Ndimande), will be published by Routledge in 2017.
\end{abstract}

\section{About the Guest Editors}

\section{Federico R. Waitoller}

University of Illinois at Chicago

fwaitoll@uic.edu

Dr. Waitoller is an assistant professor in the department of special education at the University of Illinois at Chicago. His research focuses on urban inclusive education. In particular, he examines how neoliberal informed polices, such as top-down accountability, portfolio district models, and school choice converge with inclusive education efforts, and how these initiatives affect Black and Latino students with disabilities. His research also examines teacher learning efforts and pedagogies for inclusive education.

\section{Rhoda Rae Gutierrez}

University of Illinois at Chicago

rrgutier@uic.edu

Rhoda R. Gutierrez is a PhD candidate in Educational Policy Studies, Social Foundations and cofounder of the Collaborative for Equity and Justice in Education at UIC. Her research interests include neoliberal education policy and governance, impact of public school closings on families, teacher labor force restructuring, and activist research. She recently collaborated on a research project with parent and teacher activist-researchers to understand the impact of Chicago's historic 2013 school closings from the perspective of parents. Rhoda is a parent-activist with Parents 4 Teachers, which organizes for education justice in solidarity with teachers, students and community groups, and is involved in the citywide campaign for an elected representative school board in Chicago. 


\section{SPECIAL ISSUE Restructuring and Resisting Education Reforms in Chicago's Public Schools education policy analysis archives}

ISSN 1068-2341

\section{(c)}

SOMERIGHISRESERVED Readers are free to copy, display, and distribute this article, as long as the work is attributed to the author(s) and Education Policy Analysis Archives, it is distributed for noncommercial purposes only, and no alteration or transformation is made in the work. More details of this Creative Commons license are available at http://creativecommons.org/licenses/by-nc-sa/3.0/. All other uses must be approved by the author(s) or EPAA. EPAA is published by the Mary Lou Fulton Institute and Graduate School of Education at Arizona State University Articles are indexed in CIRC (Clasificación Integrada de Revistas Científicas, Spain), DIALNET (Spain), Directory of Open Access Journals, EBSCO Education Research Complete, ERIC, Education Full Text (H.W. Wilson), QUALIS A2 (Brazil), SCImago Journal Rank; SCOPUS, SOCOLAR (China).

Please contribute commentaries at http://epaa.info/wordpress/ and send errata notes to Audrey Amrein-Beardsley at Audrey.beardsley@asu.edu

Join EPAA's Facebook community at https://www.facebook.com/EPAAAAPE and Twitter feed@epaa_aape. 


\section{education policy analysis archives editorial board}

Lead Editor: Audrey Amrein-Beardsley (Arizona State University)

Editor Consultor: Gustavo E. Fischman (Arizona State University)

Associate Editors: David Carlson, Margarita Jimenez-Silva, Eugene Judson, Mirka Koro-Ljungberg, Scott

Marley, Jeanne M. Powers, Iveta Silova, Maria Teresa Tatto (Arizona State University)

Cristina Alfaro San Diego State

University

Gary Anderson New York

University

Michael W. Apple University of

Wisconsin, Madison

Jeff Bale OISE, University of

Toronto, Canada

Aaron Bevanot SUNY Albany

David C. Berliner Arizona

State University

Henry Braun Boston College

Casey Cobb University of

Connecticut

Arnold Danzig San Jose State

University

Linda Darling-Hammond

Stanford University

Elizabeth H. DeBray University of

Georgia

Chad d'Entremont Rennie Center

for Education Research \& Policy

John Diamond University of

Wisconsin, Madison

Matthew Di Carlo Albert Shanker Institute

Michael J. Dumas University of California, Berkeley

Kathy Escamilla University of

Colorado, Boulder

Melissa Lynn Freeman Adams

State College

Rachael Gabriel

University of Connecticut

Amy Garrett Dikkers University of North Carolina, Wilmington

Gene V Glass Arizona

State University
Ronald Glass University of

California, Santa Cruz

Jacob P. K. Gross University of Louisville

Eric M. Haas WestEd

Julian Vasquez Heilig California

State University, Sacramento

Kimberly Kappler Hewitt University of North Carolina Greensboro

Aimee Howley Ohio University

Steve Klees University of Maryland

Jaekyung Lee

SUNY Buffalo

Jessica Nina Lester

Indiana University

Amanda E. Lewis University of Illinois, Chicago

Chad R. Lochmiller

Indiana University

Christopher Lubienski

Indiana University

Sarah Lubienski University of Illinois, Urbana-Champaign

William J. Mathis University of Colorado, Boulder

Michele S. Moses University of Colorado, Boulder

Julianne Moss Deakin

University, Australia

Sharon Nichols University of Texas, San Antonio

Eric Parsons University of

Missouri-Columbia

Susan L. Robertson Bristol

University, UK

Gloria M. Rodriguez

University of California, Davis
R. Anthony Rolle University of Houston

A. G. Rud Washington State University

Patricia Sánchez University of University of Texas, San Antonio Janelle Scott University of California, Berkeley

Jack Schneider College of the Holy Cross

Noah Sobe Loyola University

Nelly P. Stromquist University of Maryland

Benjamin Superfine University of Illinois, Chicago

Sherman Dorn

Arizona State University

Adai Tefera Virginia

Commonwealth University

Tina Trujillo University of California, Berkeley

Federico R. Waitoller University of Illinois, Chicago

Larisa Warhol

University of Connecticut

John Weathers University of Colorado, Colorado Springs

Kevin Welner University of Colorado, Boulder

Terrence G. Wiley Center for Applied Linguistics

John Willinsky

Stanford University

Jennifer R. Wolgemuth University of South Florida

Kyo Yamashiro Claremont Graduate University 


\section{archivos analíticos de políticas educativas consejo editorial}

Editor Consultor: Gustavo E. Fischman (Arizona State University)

Editores Asociados: Armando Alcántara Santuario (Universidad Nacional Autónoma de México), Jason Beech (Universidad de San Andrés), Angelica Buendia (Metropolitan Autonomous University, México), Ezequiel Gomez Caride (Pontificia Universidad Católica Argentina), Antonio Luzon (Universidad de Granada), José Luis Ramírez

(Universidad de Sonora, Mexico)

\section{Claudio Almonacid \\ Universidad Metropolitana de Ciencias de la Educación, Chile Miguel Ángel Arias Ortega \\ Universidad Autónoma de la \\ Ciudad de México \\ Xavier Besalú Costa \\ Universitat de Girona, España}

Xavier Bonal Sarro Universidad Autónoma de Barcelona, España

Antonio Bolívar Boitia

Universidad de Granada, España

José Joaquín Brunner Universidad

Diego Portales, Chile

Damián Canales Sánchez

Instituto Nacional para la

Evaluación de la Educación, México

Gabriela de la Cruz Flores

Universidad Nacional Autónoma de México

Marco Antonio Delgado Fuentes Universidad Iberoamericana,

México

Inés Dussel, DIE-CINVESTAV, México

Pedro Flores Crespo Universidad Iberoamericana, México

Ana María García de Fanelli Centro de Estudios de Estado y Sociedad (CEDES) CONICET, Argentina
Juan Carlos González Faraco

Universidad de Huelva, España

María Clemente Linuesa

Universidad de Salamanca, España

Jaume Martínez Bonafé

Universitat de València, España

Alejandro Márquez Jiménez Instituto de Investigaciones sobre la Universidad y la Educación, UNAM, México

María Guadalupe Olivier Tellez, Universidad Pedagógica Nacional, México

Miguel Pereyra Universidad de Granada, España

Mónica Pini Universidad Nacional de San Martín, Argentina

Omar Orlando Pulido Chaves

Instituto para la Investigación

Educativa y el Desarrollo Pedagógico (IDEP)

José Luis Ramírez Romero

Universidad Autónoma de Sonora, México

Paula Razquin Universidad de San Andrés, Argentina

José Ignacio Rivas Flores

Universidad de Málaga, España
Miriam Rodríguez Vargas

Universidad Autónoma de

Tamaulipas, México

José Gregorio Rodríguez

Universidad Nacional de

Colombia, Colombia

Mario Rueda Beltrán Instituto

de Investigaciones sobre la

Universidad y la Educación, UNAM, México

José Luis San Fabián Maroto

Universidad de Oviedo,

España

Jurjo Torres Santomé,

Universidad de la Coruña, España

Yengny Marisol Silva Laya

Universidad Iberoamericana, México

Juan Carlos Tedesco

Universidad Nacional de San

Martín, Argentina

Ernesto Treviño Ronzón

Universidad Veracruzana, México

Ernesto Treviño Villarreal

Universidad Diego Portales

Santiago, Chile

Antoni Verger Planells

Universidad Autónoma de

Barcelona, España

Catalina Wainerman

Universidad de San Andrés, Argentina

Juan Carlos Yáñez Velazco

Universidad de Colima, México 


\section{arquivos analíticos de políticas educativas conselho editorial}

Editor Executivo: Gustavo E. Fischman (Arizona State University)

Editoras Associadas: Geovana Mendonça Lunardi Mendes (Universidade do Estado de Santa Catarina), Marcia Pletsch, Sandra Regina Sales (Universidade Federal Rural do Rio de Janeiro)

\author{
Almerindo Afonso \\ Universidade do Minho \\ Portugal
}

Rosanna Maria Barros Sá

Universidade do Algarve

Portugal

Maria Helena Bonilla

Universidade Federal da Bahia

Brasil

Rosa Maria Bueno Fischer

Universidade Federal do Rio Grande do Sul, Brasil

\section{Alice Casimiro Lopes \\ Universidade do Estado do Rio de \\ Janeiro, Brasil}

\section{Suzana Feldens Schwertner}

Centro Universitário Univates

Brasil

Flávia Miller Naethe Motta

Universidade Federal Rural do Rio de Janeiro, Brasil
Alexandre Fernandez Vaz

Universidade Federal de Santa

Catarina, Brasil

Regina Célia Linhares Hostins

Universidade do Vale do Itajaí,

Brasil

Alfredo Macedo Gomes

Universidade Federal de Pernambuco

Brasil

Jefferson Mainardes

Universidade Estadual de Ponta

Grossa, Brasil

Jader Janer Moreira Lopes

Universidade Federal Fluminense e

Universidade Federal de Juiz de Fora,

Brasil

Debora Nunes

Universidade Federal do Rio Grande do Norte, Brasil

Alda Junqueira Marin

Pontifícia Universidade Católica de São Paulo, Brasil

Dalila Andrade Oliveira

Universidade Federal de Minas

Gerais, Brasil
José Augusto Pacheco

Universidade do Minho, Portugal

Jane Paiva

Universidade do Estado do Rio de

Janeiro, Brasil

Paulo Alberto Santos Vieira

Universidade do Estado de Mato

Grosso, Brasil

Fabiany de Cássia Tavares Silva

Universidade Federal do Mato

Grosso do Sul, Brasil

António Teodoro

Universidade Lusófona

Portugal

Lílian do Valle

Universidade do Estado do Rio de Janeiro, Brasil

\section{Alfredo Veiga-Neto}

Universidade Federal do Rio

Grande do Sul, Brasil 